\title{
An Evaluation of Archaeological Sites in the Vicinity of Floodwater Retarding Structure No. 2 Dry Comal Creek, Comal County, Texas
}

Cristi Assad

Follow this and additional works at: https://scholarworks.sfasu.edu/ita

Part of the American Material Culture Commons, Archaeological Anthropology Commons, Environmental Studies Commons, Other American Studies Commons, Other Arts and Humanities Commons, Other History of Art, Architecture, and Archaeology Commons, and the United States History Commons

Tell us how this article helped you.

This Article is brought to you for free and open access by the Center for Regional Heritage Research at SFA ScholarWorks. It has been accepted for inclusion in Index of Texas Archaeology: Open Access Gray Literature from the Lone Star State by an authorized editor of SFA ScholarWorks. For more information, please contact cdsscholarworks@sfasu.edu. 
An Evaluation of Archaeological Sites in the Vicinity of Floodwater Retarding Structure No. 2 Dry Comal Creek, Comal County, Texas

\section{Creative Commons License}

\section{(c) (1) (8)}

This work is licensed under a Creative Commons Attribution-NonCommercial 4.0 International License 


\section{An Evaluation of Archaeological Sites in the Vicinity of Floodwater Retarding Structure No.2}

DRY COMAL CREEK, COMAL COUNTY, TEXAS

CRISTI ASSAD

Center for Archaeological Research

The University of Texas at San Antonio

Archaeological Survey Report, No. $\mathbf{5 0}$

1978

mpra - Center Fon

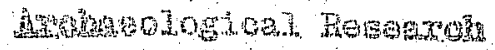


AN EVALUATION OF ARCHAEOLOGICAL SITES IN THE

VICINITY OF FLOODWATER RETARDING STRUCTURE NO. 2,

DRY COMAL CREEK, COMAL COUNTY, TEXAS

Cristi Assad

Center for Archaeological Research

The University of Texas at San Antonio

Archaeological Survey Report, No. 50

1978 
List of Figures. . . . . . . . . . . . . . ii List of Tables ................... . . i . . . . . Acknowledgments. ...................... iv Introduction ..................... 1 Previous Research................... 1 Goals of the Field Research. ............... 1 Environment of the Area. .............. 3 The Sites Tested ................. 3 $41 \mathrm{CM} 62 \ldots \ldots \ldots \ldots$ $41 \mathrm{CM} 63 \ldots \ldots \ldots \ldots \ldots$

41 CM $105 \ldots \ldots \ldots \ldots$ Additional Quarry/Workshop Sites . . . . . . . . . . . . 13 41 CM $65 \ldots \ldots \ldots$ 41 CM $66 \ldots \ldots \ldots \ldots$

$41 \mathrm{CM} 67 \ldots \ldots \ldots \ldots \ldots$

41 CM $68 \ldots \ldots \ldots \ldots$

41 CM $69 \ldots \ldots \ldots \ldots$

Summary and Recommendations................. 19

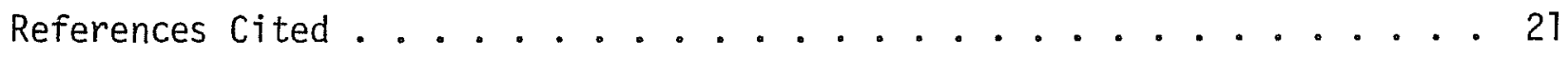

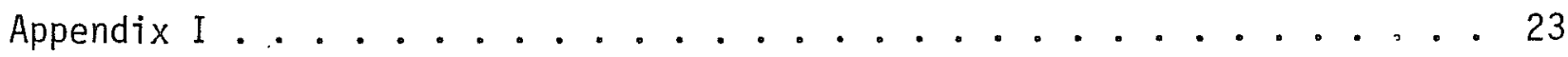

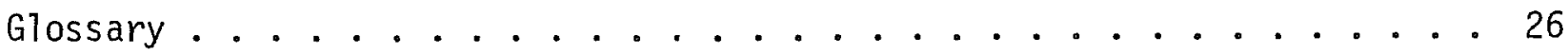




\section{LIST OF FIGURES}

Figure

1. Locations of Sites to be Affected by Floodwater Retarding

Structure No. 2............... 2

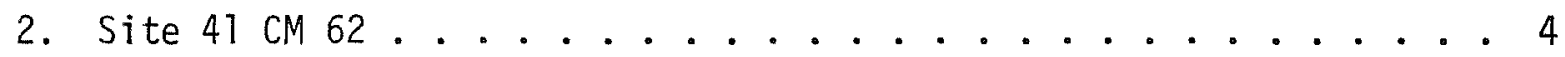

3. Sites $41 \mathrm{CM} 62$ and $41 \mathrm{CM} 63 \ldots \ldots 6$

4. Lithic Artifacts. . . . . . . . . . . . 7

5. Lithic Artifacts................. 8

6. Site 41 CM $63 \ldots \ldots . \ldots \ldots$

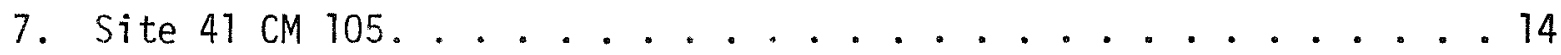

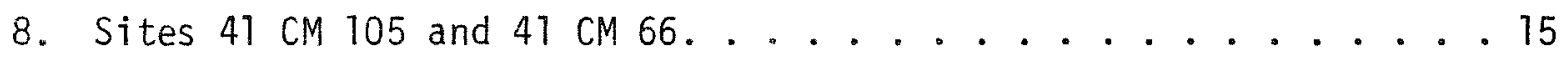




\section{LIST OF TABLES}

Table

1. Materials from the Excavation Units at $41 \mathrm{CM} 62,41 \mathrm{CM} 63$

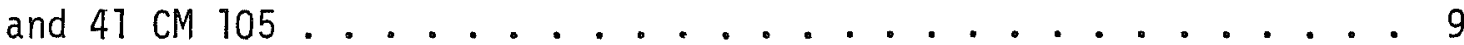

2. Surface Artifacts from $41 \mathrm{CM} 62,41 \mathrm{CM} 63$ and $41 \mathrm{CM} 105 \ldots 10$

3. Materials from Controlled Surface Collections at 41 CM 66 (Area B) . . . . . . . . . . . 18

4. Comparison of Two Quarry/Workshop Collections ......... 24

5. Comparison of Flake Categories at Four Quarry/Workshop Sites in Comal County, Texas. . . . . . . . . . 25 


\section{ACKNOWLEDGMENTS}

I wish to express my gratitude to the many individuals who were instrumental in the successful completion of this project. Mr. Carl Englerth, District Conservationist of the Soil Conservation Service, New Braunfels, Texas, was exceedingly helpful in dealing with the several landowners involved.

A11 of the landowners were very cooperative and trusting in allowing us to roam across their land. Special thanks and appreciation are extended to Mr. Herbert Kreusler and his family, whose hospitality and cooperation we received while working at $41 \mathrm{CM} 62$.

Waynne Cox and Tom Miller, both of the Center for Archaeological Research (CAR), The University of Texas at San Antonio, were invaluable in assisting me not only with the arduous field work but also with many ideas and observations. Thanks are also due to Augustine Frkuska (CAR) for the excellent job of performing the necessary laboratory work on the collected materials and also for drafting some of the report illustrations. Fred Valdez, Jr. and A. Joachim McGraw (both of CAR) were very helpful in suggesting ideas for the site descriptions.

Last7y, many thanks to Dr. Thomas R. Hester, Director of the Center, and Mr. Jack D. Eaton, Assistant Director, for their understanding, suggestions, advice and guidance throughout the duration of this project. 


\section{INTRODUCTION}

During September and October of 1977, 10 days of limited testing and survey were carried out by personnel from the Center for Archaeological Research (CAR), The University of Texas at San Antonio, under the supervision of Dr. Thomas R. Hester. The work was conducted under the terms of Purchase Order No. 40-74421501 issued by the United States Department of Agriculture (USDA) Soil Conservation Service (SCS). The sites tested were in the area to be modified by the construction of Floodwater Retarding Structure No. 2 located on Dry Comal Creek in Comal County, south central Texas (Fig. 1). The testing was the second phase of investigation, following a survey in 1974, in the areas to be modified by the construction of Floodwater Retarding Structures 1 and 2 (Hester, Bass and Kelly 1975). In 1975, Timited testing and additional survey were undertaken in the area affected by Structure No. 1 (Kelly and Hester 1975a; 1975b).

The field work done in 1977, the subject of this report, was supervised by Cristi Assad, aided by Waynne Cox and Thomas Miller. All field notes, maps and artifacts are on file at the Center for Archaeological Research.

\section{PREVIOUS RESEARCH}

As of November 1977, 105 archaeological sites in Comal County had been recorded with the Texas Archeological Research Laboratory, Austin, Texas. Hester, Bass and Kelly (1975) previously have discussed the major site types and prehistory of the area. Further archaeological surveys in the immediate areas of Floodwater Retarding Structures 1 and 2 (including the current project) have increased the number of archaeological sites in the Comal River Watershed from 14 to 33 since the initial survey in late 1974 (Hester, Bass and Kelly 1975; Kelly and Hester 1975a).

\section{GOALS OF THE FIELD RESEARCH}

The intent of the current project was to fulfill the archaeological recommendations for the area of Floodwater Retarding Structure No. 2 (Hester, Bass and Kelly 1975) and to determine if further research was necessary at the archaeological sites to be directly affected by the planned construction of the dam and related facilities.

The overall project area includes 77 acres for the dam and spillway, 25 acres in the borrow pit area and 54 acres for construction of the sediment pool. An additional 557 acres wi11 be subject to temporary inundation (USDA and SCS 1975).

Eight archaeological sites are recorded in the Floodwater Retarding Structure No. 2 area. Hester, Bass and Kelly (1975) recommended three occupation sites

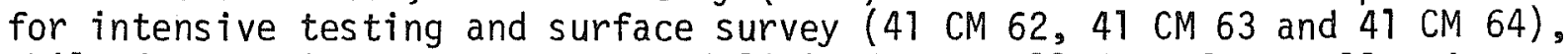
while further intensive survey and limited controlled surface collecting were recommended for the remaining five quarry/workshop sites (41 CM 65, $41 \mathrm{CM} 66$, $41 \mathrm{CM} \mathrm{67,41} \mathrm{CM} 68$ and 41 CM 69). The aim of the current project, therefore, was to determine the extent of deposit (both horizontally and vertically) and the 
This page has been

redacted because it

contains restricted

information. 
cultural context of the three occupation sites by excavation and intensive surface reconnaissance. For the quarry/workshop sites, surface reconnaissance was carried out in an attempt to determine the extent, intensity and nature of the cultural debris.

One new site (41 CM 105) was found; due to its location in the borrow pit area, testing was deemed necessary. Because the $41 \mathrm{CM} 64$ site could not be located during the current survey, the time originally allocated to investigate this site was used to test 41 CM 105.

\section{ENVIRONMENT OF THE AREA}

This brief description of the environment and geology of the Comal River Watershed area applies to all of the sites tested and surveyed within the impact zone of Floodwater Retarding Structure No. 2.

The area is situated near the southeastern edge of the Edwards Plateau and is in the Balcones Fault Zone (Blair 1950). Dry Comal Creek is, geologically, part of the Edwards Limestone Formation of the Lower Cretaceous (Barnes 1974). The chert-bearing Edwards Formation was a valuable source of raw material for the aboriginal populations, as evidenced by the numerous and extensive quarry-workshops in the area. Much of the soil in the study area is of the Del Rio Clay Series (USDA and SCS 1975).

Dry Comal Creek is a natural stream with ephemeral flow. At the present, some springs along the creeks flow during wet seasons but not during the dry seasons (USDA and SCS 1975).

\section{THE SITES TESTED}

\section{$41 \mathrm{CM} 62$}

Although originally described as a burned rock midden in the preliminary survey (Hester, Bass and Kelly 1975), recent re-evaluations suggest 41 CM 62 can better be described as an extensive terrace campsite/quarry. The site is situated atop a steep terrace $10 \mathrm{~m}$ above Dry Coma 1 Creek. Site dimensions are $200 \mathrm{~m}$ north/ south by $150 \mathrm{~m}$ east/west with a drainage at both the northern and southern boundaries (see Fig. 1). Although relic collectors have been active in the area for many years ( $H$. Kreusler, personal communication*), many prehistoric lithic artifacts were still observed on the surface of the site prior to subsurface testing. Along the terrace edge and especially in the southern part of the site, quarry activities are to be found in the form of sampled chert (having only one or two flakes removed), chert nodular cores, some tabular chert cores and large quarry blanks (see Fig. 2). Limestone bedrock and chert, the majority of which is nodular, are found eroding out along all of the terrace edge.

* Mr. Kreusler's family has lived in the area since the 1860s. 


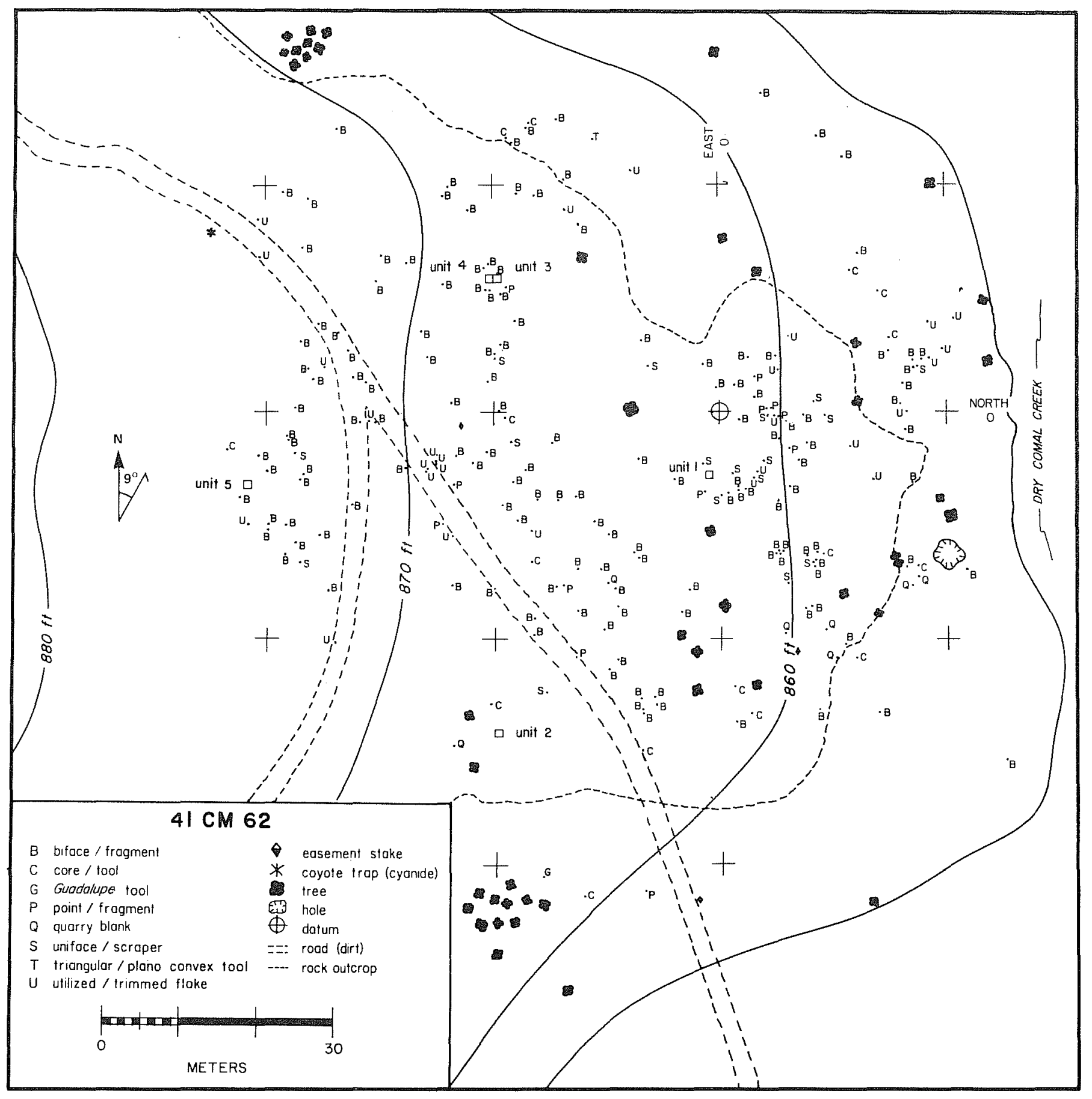

Figure 2. Site $41 \mathrm{CM}$ 62. Shown here are the locations of excavation units and mapped-in surface artifacts. 
The vegetation growing at 41 CM 62 is composed of various grasses and sma 11 clusters of oak trees. A few large juniper trees are found among the oaks. Charred, uprooted stumps on the site are remaining evidence of land clearing by the property owners. The vegetal growth at $41 \mathrm{CM} 62$ is minimal when compared to the majority of the Dry Comal Creek drainage which is within the flood pool area of Floodwater Retarding Structure No. 2.

Subsurface examination of the site was conducted by excavation of five $1 \mathrm{~m}^{2}$ test units. These units were arbitrarily distributed across the site to test for depth and nature of the cultural deposits. All soil was screened through 1/4-inch wire mesh. Vertical control for all units was established at 5-cm intervals. Artifact deposits at all units did not exceed $15 \mathrm{~cm}$ (see Table 1 for artifact proveniences from the excavation units). One feature was noted during the testing operation: a possible hearth in Unit 5. Although the site as a whole contains an extensive surface scattering of 1 ithic debris, subsurface examination shows the vertical depths of cultural deposits are minimal and occur in a thin layer across the terrace.

In addition to limited testing, a detailed site map was drawn (see Fig. 2). The entire prehistoric site was also intensively surveyed and all observed artifacts were collected, flagged or mapped in place (see Fig. 3,a and Table 2).

The results of the testing operations at $41 \mathrm{CM} 62$ suggest the locality once served as a preferred occupational site at different periods throughout the long history of aboriginal occupations in the region. The Late Paleo-Indian, Pre-Archaic and all three phases of the Archaic (Early, Middle and Late) periods are represented at $41 \mathrm{CM} 62$ in the form of 7 ithic artifacts. A probable Angostura point (Fig. 4,a) of the Late Paleo-Indian time period, a Pre-Archaic "Early Triangular" point (Hester 1971; Fig. 4,f) and a Guadalupe tool (Hester and Kohnitz 1975), and two Early Archaic (Travis and Nolan) dart points (Fig. 4,g,h) were recovered. Other diagnostic projectile points at the site include a Pedernales from the Middle Archaic period (Fig. 4,c) and an Ensor and Montell from the Late Archaic (Fig. 4,d,e). The Montell point was found in the first level $(0-5 \mathrm{~cm})$ of Unit 1. Five unclassified dart points or fragments were also found on the surface of the site.

Other lithic artifacts from 41 CM 62 include two triangular plano-convex tools (Fig. 5,d,e). These triangular plano-convex tools are similar to clear Fork tools (Howard 1973; Hester, Gilbow and Albee 1973), but they are shorter and have a wider base than a Clear Fork tool found in a bulldozer cut at 41 CM 63 (Fig. 5,a). A tool similar to the artifacts at $41 \mathrm{CM} 62$ was found at the La Jita Site, Uvalde County, and referred to as a "gouge-scraper" (Hester 1971).

Many other lithic artifacts from the surface of $41 \mathrm{CM} 62$ were either noted or collected. A general descriptive term was given to each of the surface artifacts noted; the majority were not collected (Table 2). The purpose of the intensive mapping of $41 \mathrm{CM} 62$ was to ascertain surface distribution of 7 ithic artifacts within a limited field work period. All of the surface artifacts are inventoried in Table 2 and plotted on the site map of 41 CM 62 (Fig. 2).

\section{$41 \mathrm{CM} 63$}

As with 41 CM 62, this site was originally described by Hester, Bass and Kelly (1975) as a burned rock midden. Recent re-evaluations based on intensive 


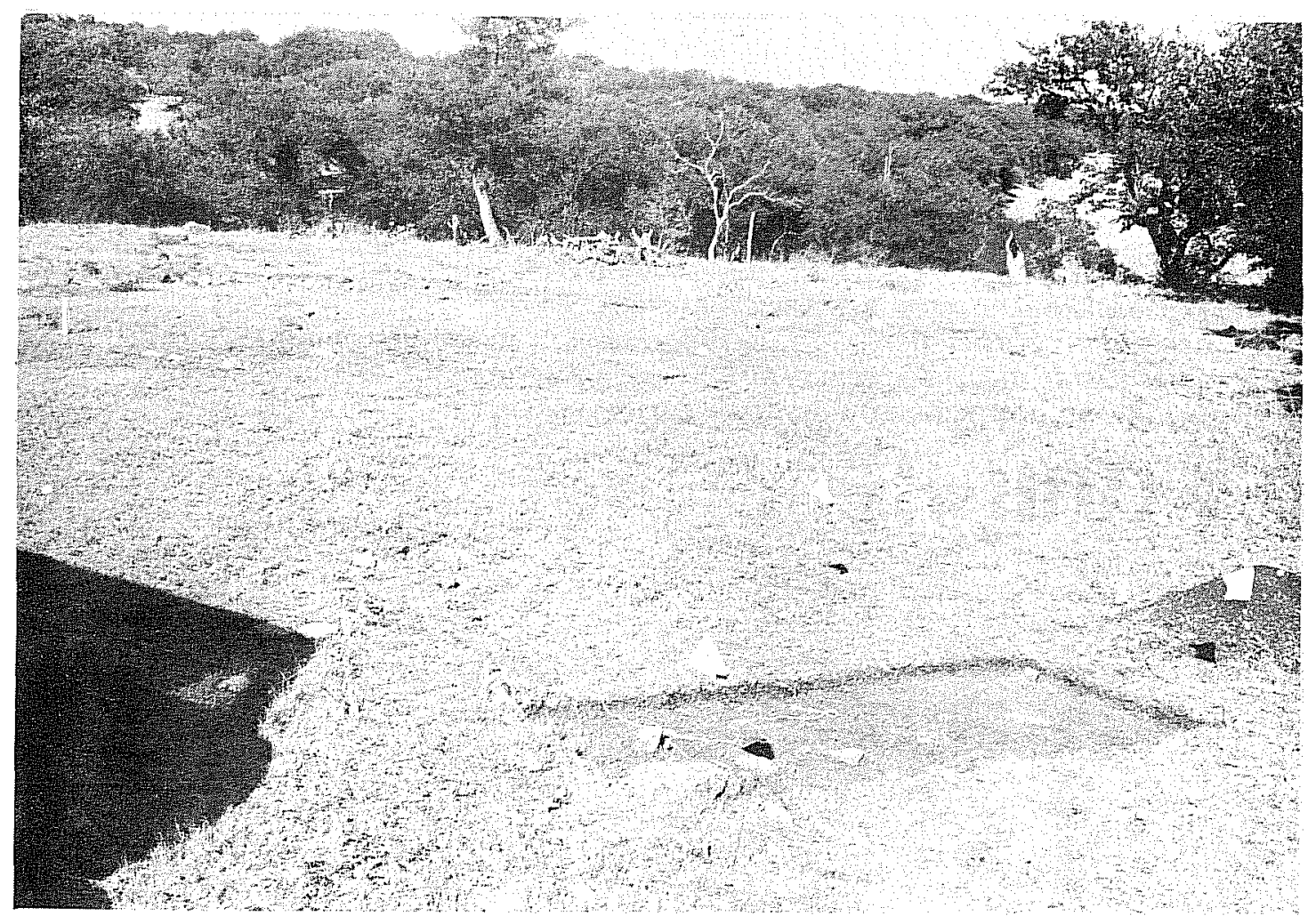

a

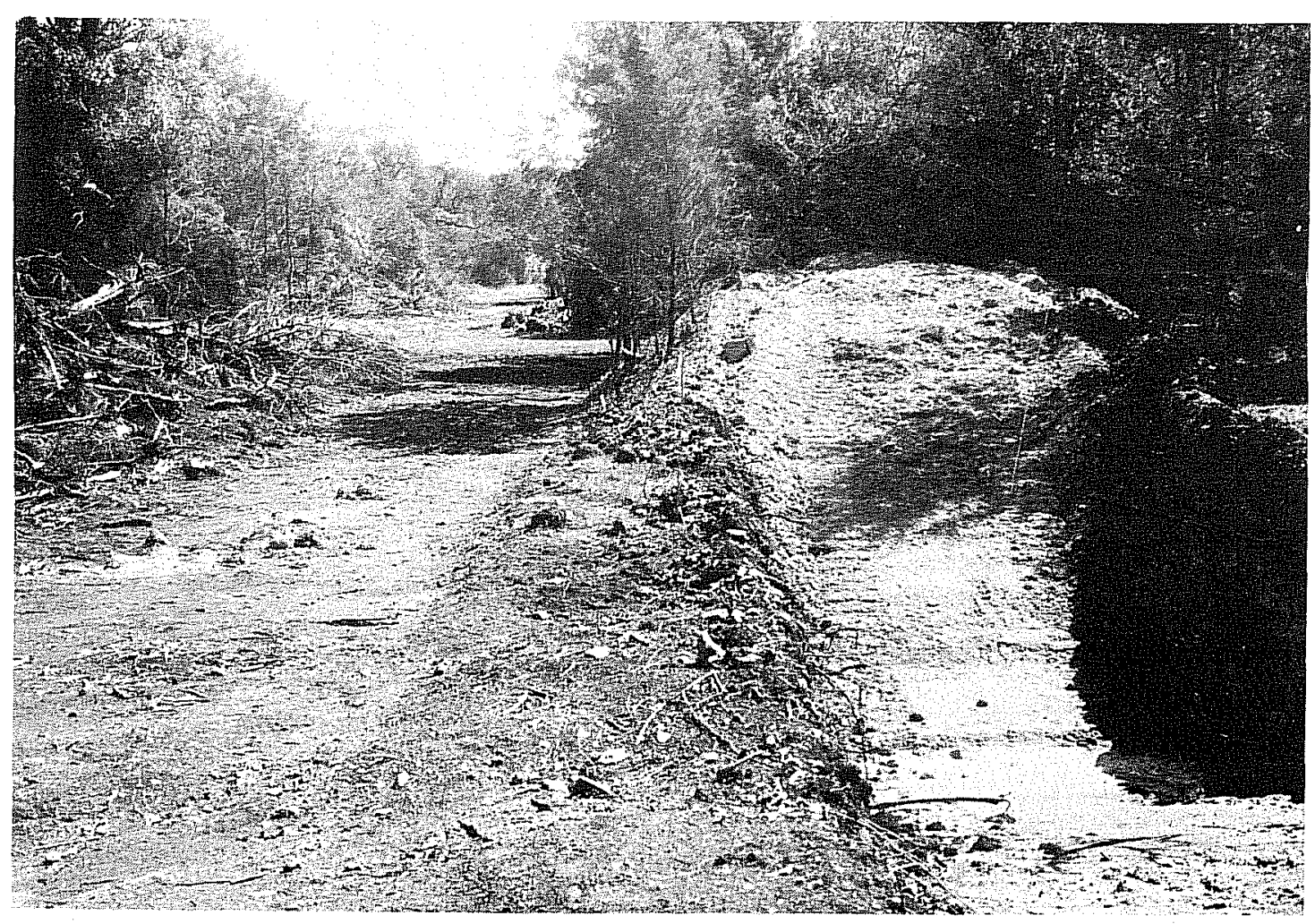

b

Figure 3. Sites $41 \mathrm{CM} 62$ and $41 \mathrm{CM}$ 63. a, Units 3 and 4 at $41 \mathrm{CM} \mathrm{62;} \mathrm{flags}$ indicate locations of surface artifacts. b, bulldozer cut at $41 \mathrm{CM} 63$. 


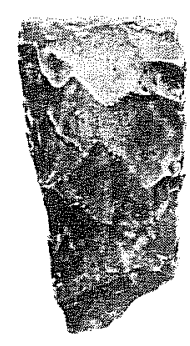

a

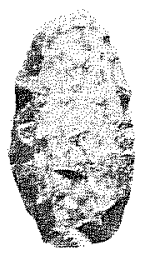

b

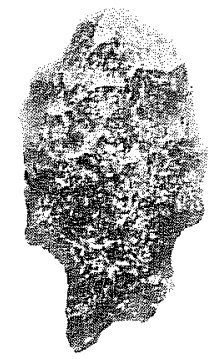

$c$

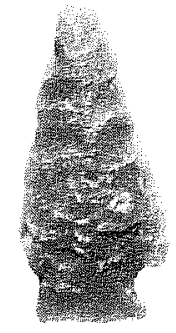

d

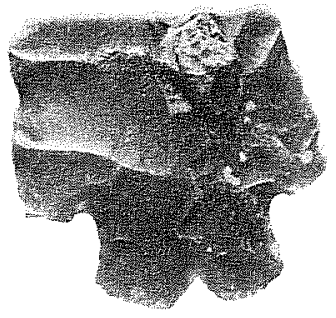

e

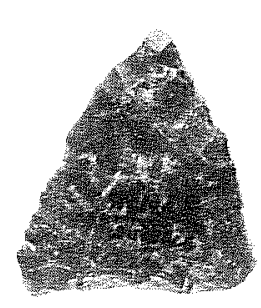

f

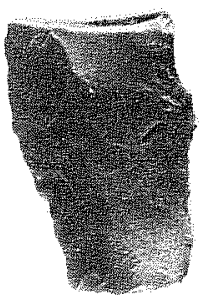

g

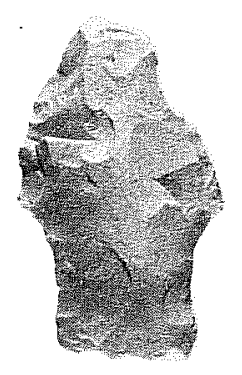

h
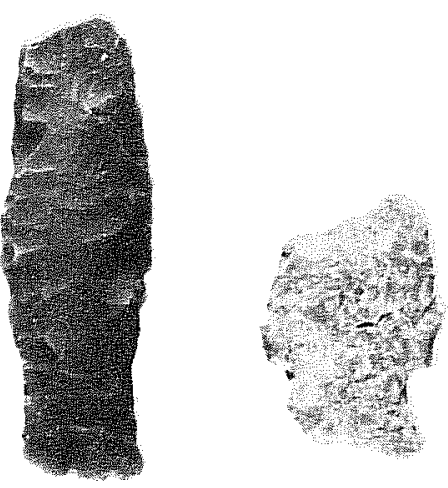

i
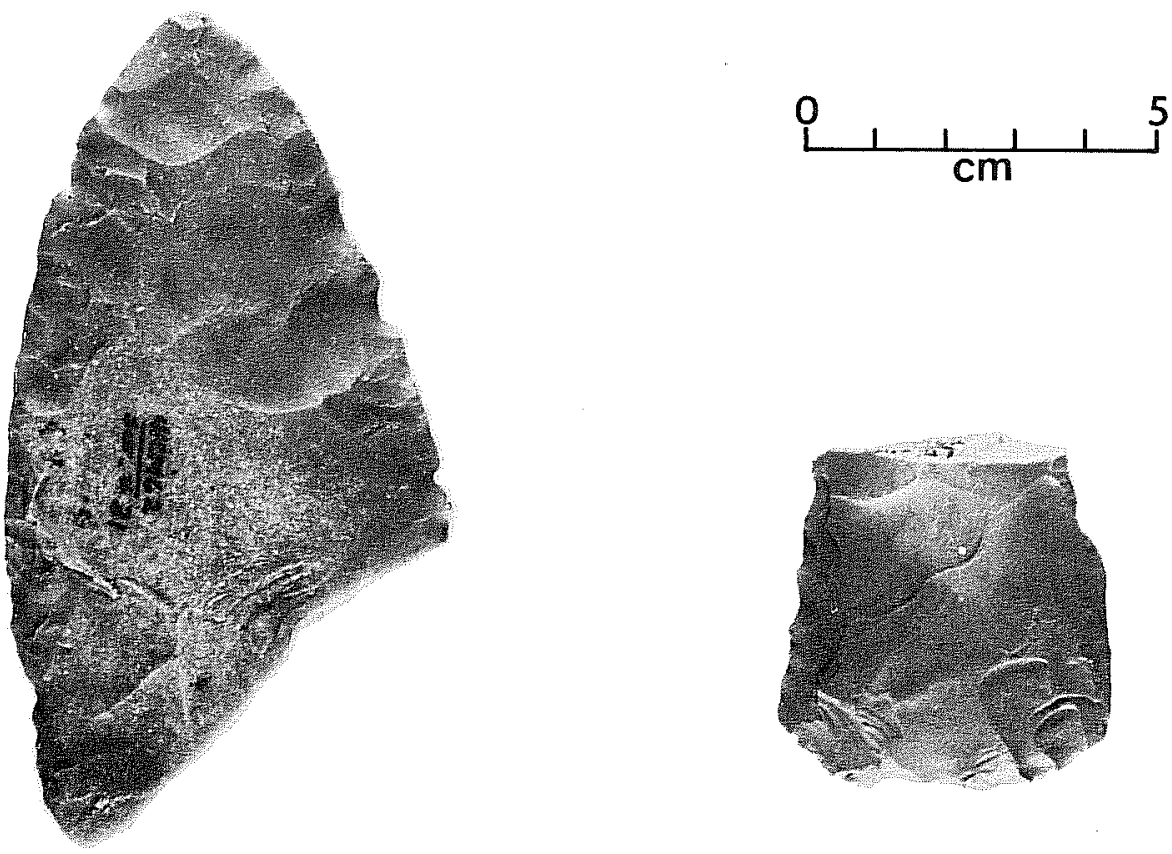

k

Figure 4. Lithic Artifacts. 41 CM 62: a, Angostura; c, Pedernales; d, Ensor; e, Montell; f, "Early Triangular"; g, Travis; h, Nolan; $k-1$, bifaces. 41 CM 63: $i$, Nolan. $41 \mathrm{CM}$ 105: b, Angostura; $j$, "Early Corner Notched." 


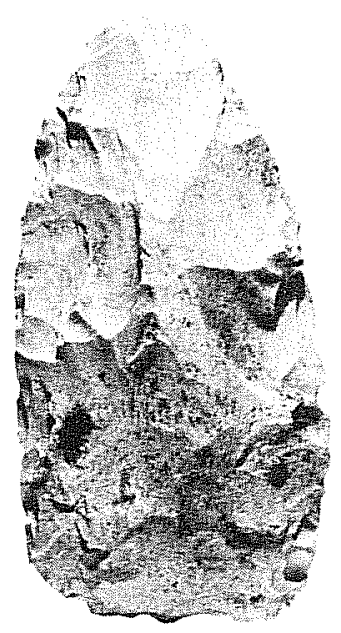

a

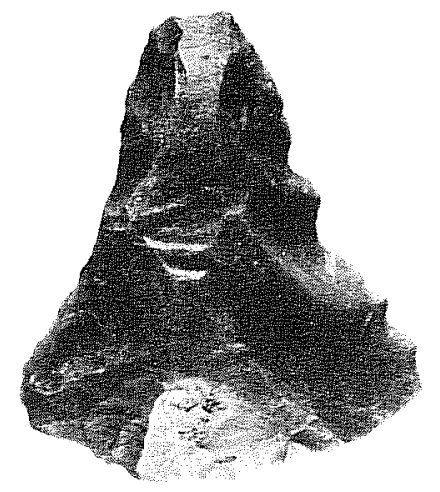

d

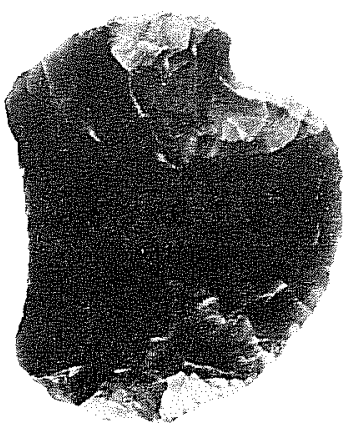

g

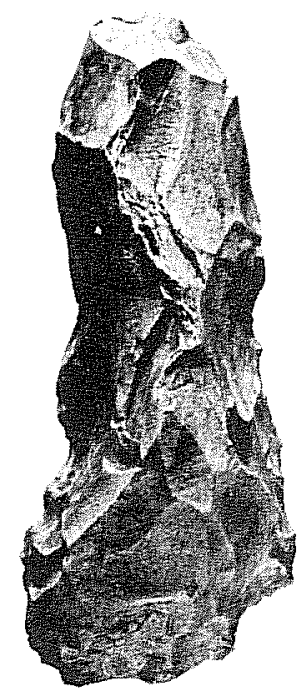

b

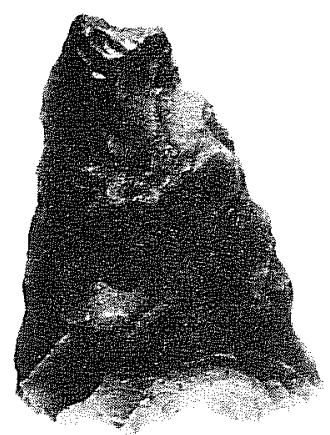

e

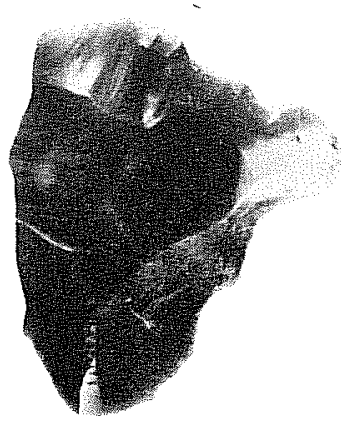

h

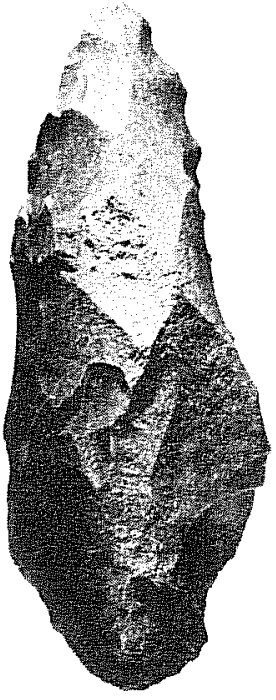

C

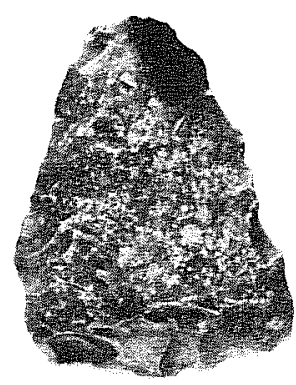

f

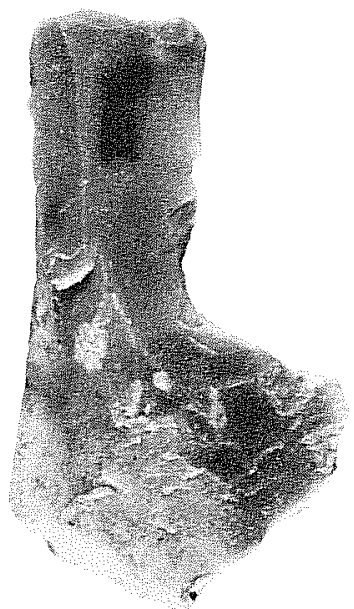

i

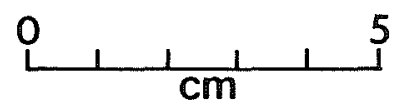

Figure 5. Lithic Artifacts. $41 \mathrm{CM}$ 62: d-e, triangular plano-convex tools; g-i, bifaces. 41 CM 63: a, Clear Fork tool; b, Guadalupe tool; f, triangular plano-convex tool. 41 CM 105: c, Guadalupe tool. 
TABLE 1. MATERIALS FROM THE EXCAVATION UNITS AT 41 CM 62, 41 CM 63 and 41 CM 105

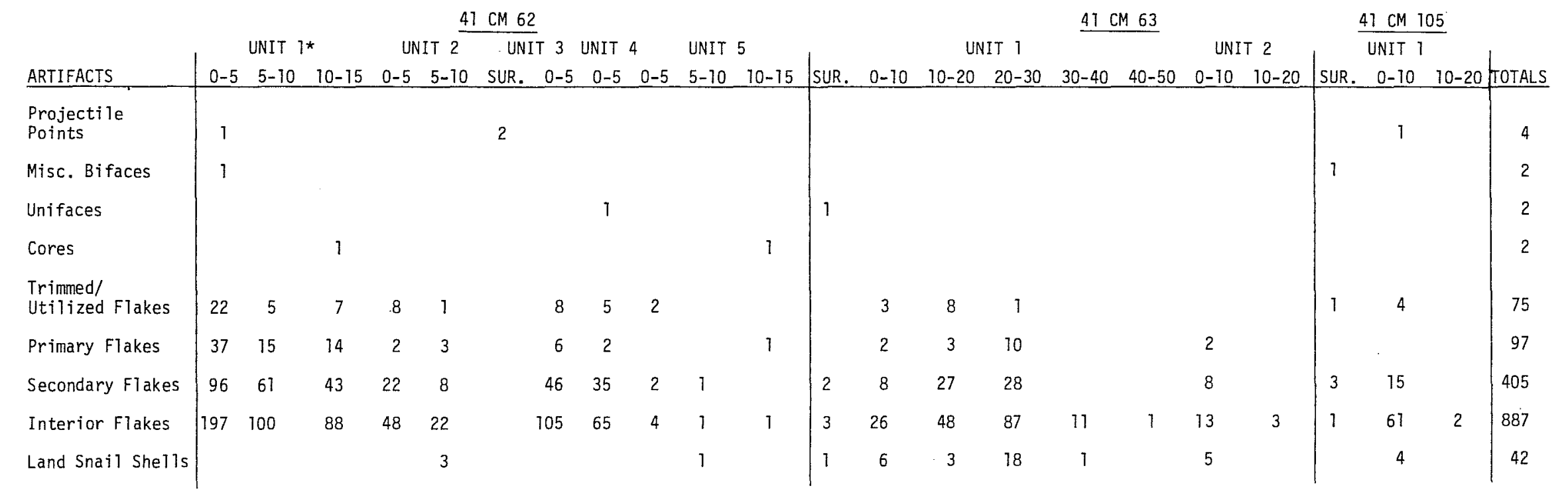


TABLE 2. SURFACE ARTIFACTS FROM 41 CM 62, 41 CM 63 AND 41 CM 105

\begin{tabular}{|c|c|c|c|c|c|c|c|c|}
\hline \multirow[b]{2}{*}{ ARTIFACT } & \multicolumn{2}{|l|}{$41 \mathrm{CM} 62$} & \multicolumn{3}{|c|}{$41 \mathrm{CM} 63$} & \multicolumn{3}{|c|}{$41 \mathrm{CM} 105$} \\
\hline & Gen. Surface & Gen. Surface & Unit 3 & Unit 4 & Unit 5 & Unit 6 & Gen. Surface & TOTALS \\
\hline Bifaces (complete) & 40 & 1 & & & & & & 41 \\
\hline Bifaces (fragments) & 34 & 4 & & & & & & 38 \\
\hline Biface Tips & 20 & & & & & & & 20 \\
\hline Biface Bases & 51 & 2 & & & & & & 53 \\
\hline Quarry B Tanks & 7 & & & & & & & 7 \\
\hline Cores & 11 & & & & & & & 11 \\
\hline Core Tools & 5 & & & & & & & 5 \\
\hline Uniface Tools & 15 & & & & & & & 15 \\
\hline Guadalupe Tools & 1 & 1 & & & & 1 & 3 & 6 \\
\hline Points/Point frags. & 10 & 2 & & & & & 8 & 20 \\
\hline $\begin{array}{l}\text { Trimmed/Utilized } \\
\text { Flakes }\end{array}$ & 27 & 1 & 3 & 4 & 2 & 2 & 3 & 42 \\
\hline Secondary Flakes & & & 1 & 1 & 4 & 3 & & 9 \\
\hline Interior Flakes & & & 1 & 6 & 4 & 3 & & 14 \\
\hline Other Materials & $5^{*}$ & $2^{\star \star}$ & & & & & \rceil $* * *$ & 8 \\
\hline
\end{tabular}

*Including: a hammerstone, uniface tool, perforator, triangular plano-convex tool and "mano-7ike" rock **One Clear Fork tool and one triangular plano-convex tool

***One triangular plano-convex tool. 
surface survey and limited excavations suggest the locality was a prehistoric occupation site on a lower terrace of Dry Comal Creek. No evidence of a burned rock accumulation was found during the recent survey operations.

The centerline for Floodwater Retarding Structure No. 2 runs through a segment of $41 \mathrm{CM}$ 63. Prior to the current archaeological investigations, about $40 \%$ of the site was destroyed, especially along the dam centerline (see Fig. 3,b and Fig. 6).

The surface of $41 \mathrm{CM} 63$ has an undulating appearance probably due to ongoing erosion and recent activities involved with preparation for the construction of Floodwater Retarding Structure No.2. The dimensions of 41 CM 63 are roughly $100 \mathrm{~m}$ east-west $\times 150 \mathrm{~m}$ north-south. Dry Comal Creek is directly to the west of the site. Erosion of cultural material from the site is visible along the creek edge.

Vegetation at 41 CM 63 consists primarily of thick growths of juniper trees in undisturbed portions of the site. Sparse grasses are scattered over much of the open eroded and defoliated surface.

Subsurface examination of 41 CM 63 consisted of two $1 \mathrm{~m}^{2}$ test units excavated by trowels and screened through 1/4-inch wire mesh. Vertical control was established by the use of $10-\mathrm{cm}$ intervals.

Unit 1 was located at the edge of dense juniper growth. It was excavated to $50 \mathrm{~cm}$ in depth before reaching a culturally sterile level. Unit 2 was located in an open and possibly eroded area. A culturally sterile level was reached at a depth of $20 \mathrm{~cm}$. The artifacts recovered from the excavation units are inventoried in Table 1 .

Surface examination included a collection of four $1 \mathrm{~m}^{2}$ units (Units 3-6) from an undisturbed area of the site. In addition to the controlled collection of artifacts, a general surface collection was made of potentially diagnostic artifacts which were dispersed across the site. These artifacts were arbitrarily collected and mapped in (no detailed provenience was recorded for artifacts found in bu11dozer cuts). Litule in the way of controlled collections was carried out due to the disturbed nature of the site. All artifacts from both surface collections are inventoried in Table 2. All units and collected artifacts are plotted on the site map (Fig. 6).

The lithic artifact analysis of 41 CM 63 is limited here to an identification of chronologically diagnostic artifacts. All of the lithic artifacts are listed in Tables 1 and 2. A Guadalupe tool (Fig. 5,b) of the Pre-Archaic, a Nolan projectile point (Fig. 4,i) of the Early Archaic and an Archaic Clear Fork tool (Fig. $5, a)$ were collected from the surface. A triangular plano-convex tool (Fig. 5,f) similar to a clear Fork tool was also found. The chronological age of these triangular tools is not known but they probably date to the Archaic period. Some other lithic materials observed on the surface of the site, but not collected, were trimmed/utilized flakes, cores, a variety of bifaces (whole and fragmented preforms and blanks) and flakes. All of the diagnostic artifacts were from the general surface collection. 
This page has been

redacted because it

contains restricted

information. 
While surveying the borrow pit area of Floodwater Retarding Structure No. 2, a previously unrecorded site was found (see Fig. 1). $41 \mathrm{CM} 105$ is a smal1 prehistoric occupation site located on an eastern upper terrace of Dry Comal Creek. The site is ca. $60 \times 60 \mathrm{~m}$ and is located near the 830-foot contour line as represented on USGS topographic maps (see Fig. 7). A water tank lies northwest of $41 \mathrm{CM}$ 105, and a small part of the site may have been destroyed by its construction. A ranch complex (house, barn, outbuildings, etc.) lies southward

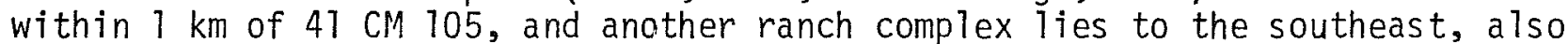
within $1 \mathrm{~km}$ of the site. In addition to alteration of the site by construction of the water tank, obvious damage to $41 \mathrm{CM} 105$ has been caused by a dirt road, intense grazing of cattle and some erosion.

The surface of $41 \mathrm{CM} 105$ is relatively level (see Fig. 8,a). There are a few shallow erosional channels across the site. Visible concentrations of cultural material were found in these cuts.

The vegetation at $41 \mathrm{CM} 105$ is currently being affected by intense cattle grazing. Sparse grasses and a few juniper trees are present.

Since the site is in the borrow pit area of Floodwater Retarding Structure No. 2, the survey crew decided that further investigation would be necessary to evaluate its archaeological potential prior to $i$ ts destruction. A $1 \mathrm{~m}^{2}$ test unit was excavated to a depth of $20 \mathrm{~cm}$. Limestone bedrock was encountered at that depth. The unit was dug by trowel in arbitrary $10-\mathrm{cm}$ intervals, and all soil was screened through $1 / 4-i n c h$ wire mesh. The cultural material recovered from the unit is inventoried in Table 1. The excavation unit was arbitrarily placed in order to obtain information of the depth of the cultural deposit and for possible recovery of stratified diagnostic artifacts which would aid in the evaluation of the archaeological significance of 41 CM 105.

The surface of the site was intensively surveyed and sketch-mapped, and iithic artifacts were collected (they did not include the many flakes or other miscellaneous debris). Finished artifacts include two Guadalupe tools (Fig. 5,c), an Angostura point (Fig. 4,b), "Early Corner Notched" projectile point fragments (Fig. 4,j), four additional unidentified dart point fragments and two preforms. The surface artifacts are inventoried in Table 2. The test unit and the collected surface artifacts are plotted in Fig. 7.

\section{ADDITIONAL QUARRY/WORKSHOP SITES}

A natural resource of prime importance in the Comal River Watershed is the exposure of the chert-bearing Edwards Limestone Formation. Quarry/workshop sites (41 CM 65, 41 CM 66, 41 CM 67, 41 CM 68 and 41 CM 69) extend along both sides of Floodwater Retarding Structure No. 2, both above and below the Soil Conservation Service easement Tine of 848.8 feet (see Fig. 1). Vegetation on these sites varies from very dense to sparse grasses and brush throughout the area. In virtually every area where chert is eroding out along the edge of the creek and the upper terraces, sampled or broken nodules of chert can be found. Lithic debris on these sites varies from a light scatter to heavy concentrations. 


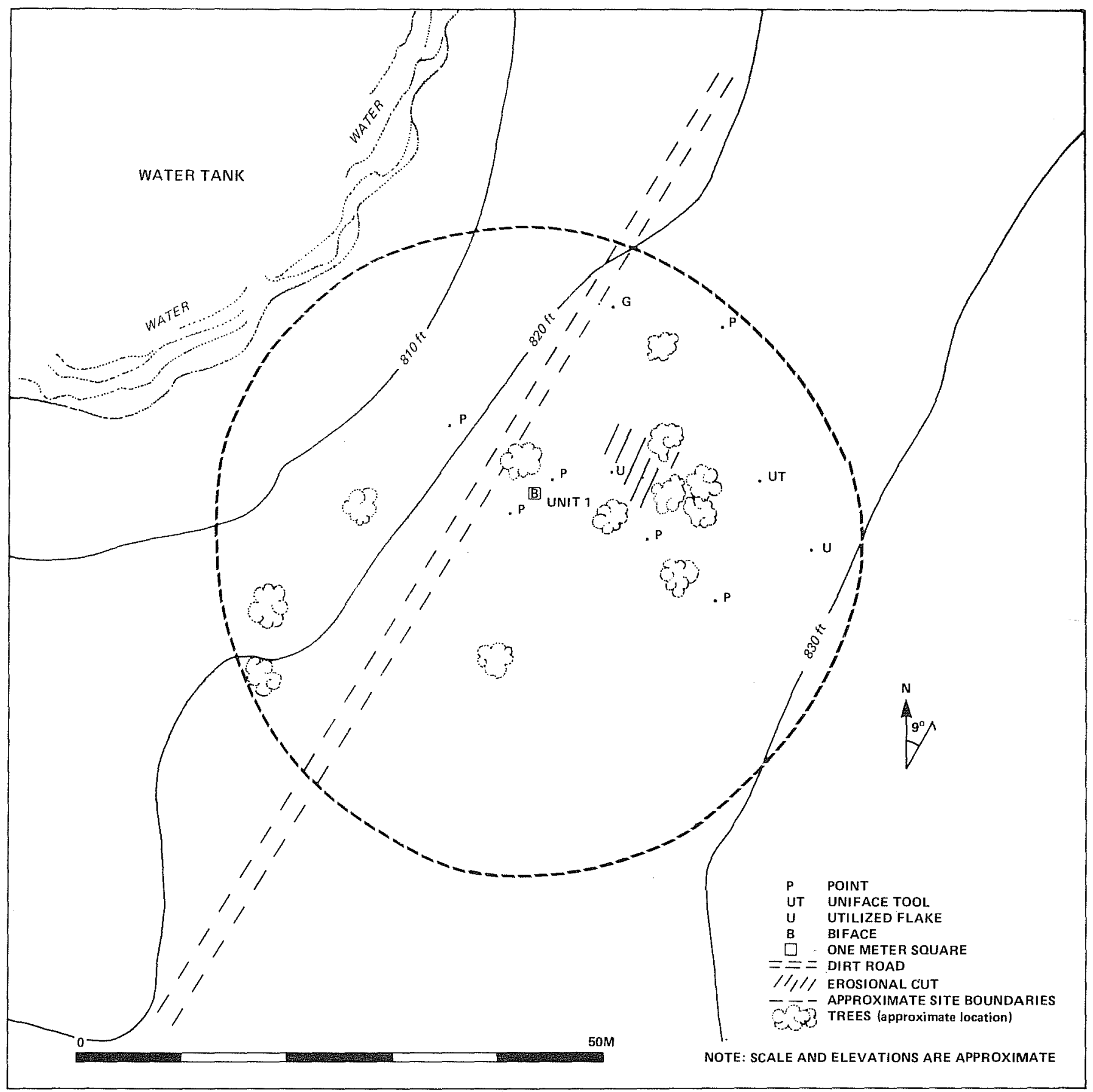

Figure 7. Site $41 \mathrm{CM}$ 105. Location of excavation unit and surface artifacts. 


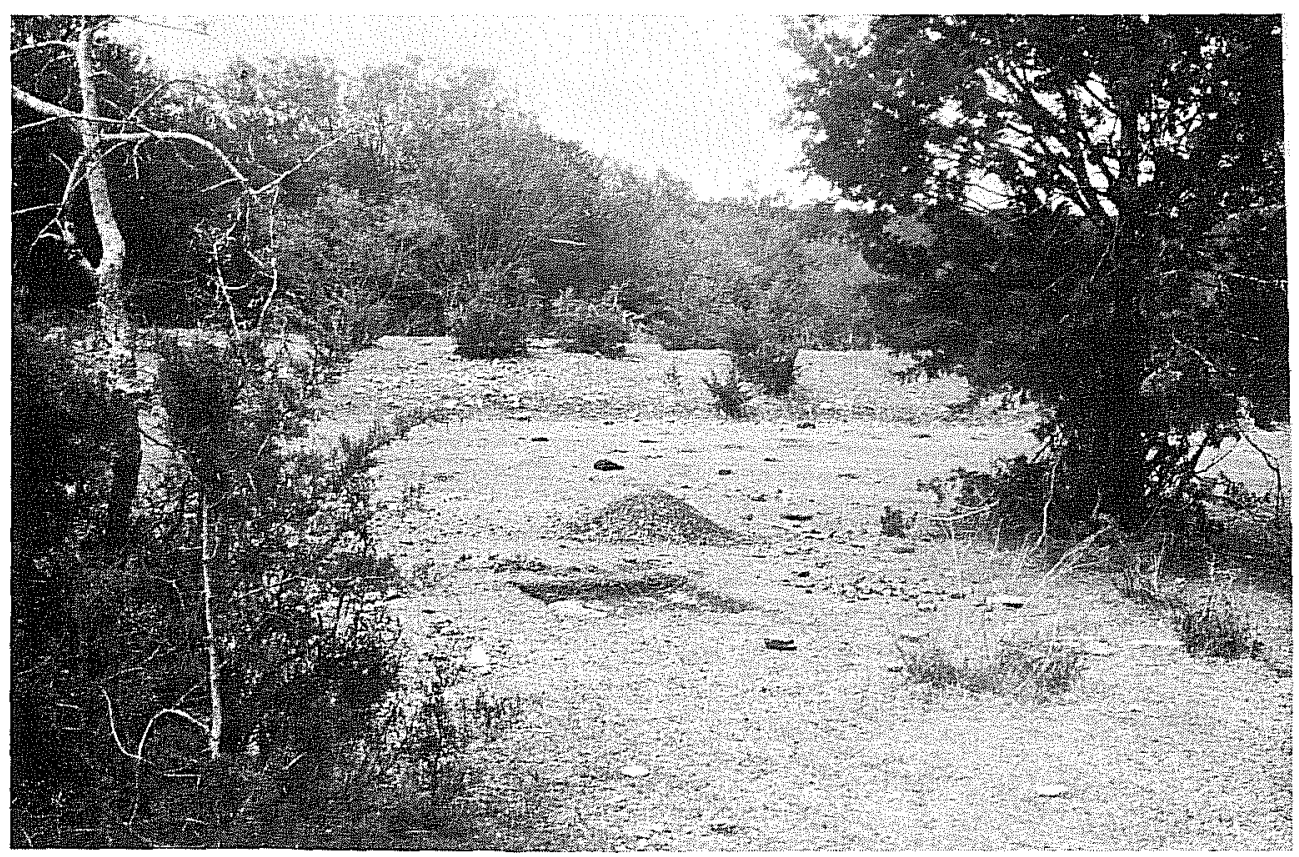

a

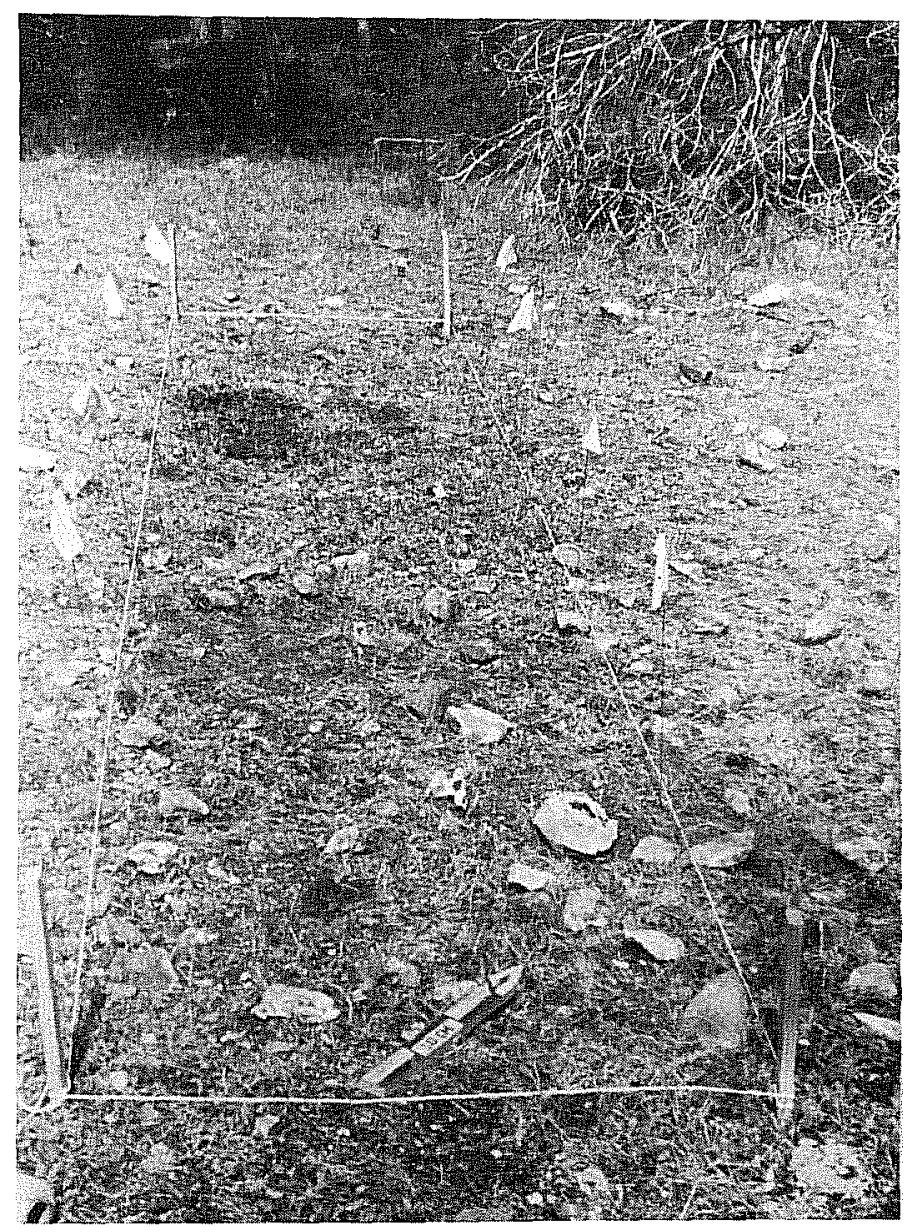

b

Figure 8. Sites $41 \mathrm{CM} 105$ and $41 \mathrm{CM}$ 66. a, Unit 1 at $41 \mathrm{CM} 105$. b, Area $B$ at 41 CM 66; surface collection Units 6-10. 
Because aboriginal inhabitants did not confine their quarrying activities to any particular location, it is extremely difficult to define site boundaries.

The following is a brief description of each of the quarry/workshop sites and of the results of the controlled surface collection from one of them (41 CM 66). No artifacts were collected from the other quarry/workshop sites.

\section{$41 \mathrm{CM} 65$}

$41 \mathrm{CM} 65$ is on the east side of Dry Comal Creek. It extends north $2 \mathrm{~km}$ from the northernmost end of $41 \mathrm{CM} \mathrm{63.} \mathrm{The} \mathrm{site} \mathrm{is} \mathrm{concentrated} \mathrm{in} \mathrm{two} \mathrm{large} \mathrm{areas} \mathrm{(A}$ and $\mathrm{B}$; see Fig. 1) which are separated by about $600 \mathrm{~m}$ of little or no chert outcropping. Area $A$ is rough7y $850 \mathrm{~m}$ in length extending directly north of $41 \mathrm{CM}$ 63 , and Area $B$ is about $500 \mathrm{~m}$ in length at the opposite end of the site. An underground pipeline installation cut a 15-m wide strip through the southern extension of Area B. Both areas extend to or outside of the easement line.

The east side of the creek has a more gradual rise in elevation than the west side at this locale. Many small drainages cut through parts of the site, and in times of heavy rainfall, this side is probably subject to flooding.

At points where chert nodules are exposed, there are indications of quarrying activities, and some nodules exhibit intensive use. Many large bifacial quarry blanks were observed; they were $10-15 \mathrm{~cm}$ in length, with all or most of the cortex removed. Secondary and interior flakes are present along with various bifaces (quarry blanks, fragmented and medium to sma 11 sized) and cores scattered throughout the concentrations; few primary flakes were noted.

The terrain of the site is composed of 7 imestone bedrock in the south (especially in Area A) to light brown/orange soil with 1 imestone rock and chert nodules eroding out in the northern parts. Juniper and oak, along with brushy vegetation, are extremely dense in spots.

\section{CM 66}

41 CM 66 is on the west side of Dry Comal Creek. The site is bounded by the dam and spillway area on the south. A drainage separates this site and 41 CM 62 at the north (see Fig. 1). The site is over $2 \mathrm{~km}$ in length and has been divided into four major areas of Tithic concentrations (A through $D$; see Fig. 1). Chert nodules are exposed from the creek bed up to the 870-foot contour 1 ine as well as throughout the site itself. This is approximately the elevation where the downward slope ends and the terrain levels out. The flood pool easement line is over $20 \mathrm{~m}$ below this contour.

Area $A$ is over $300 \mathrm{~m}$ in length. Some unmodified chert has been broken by heavy machinery in this area but there was also extensive aboriginal activity. The 
lithic scatter in Area $A$ is light, with many interior flakes and few primary or secondary flakes seen. The soil is a bright red/orange color.

Area $B$ is about $550 \mathrm{~m}$ in length and is separated from Area A by $200 \mathrm{~m}$ with little to no lithic scatter. Area $B$ is heavily littered with cores, large and small bifaces, secondary flakes and interior flakes. The soil matrix is a red/ orange color with many small chunks of chert buried in it.

Two controlled surface collections were made in Area B (see Figs. 1 and 8,b). Each of the two collection zones consisted of five $1 \mathrm{~m}^{2}$ units. These ran parallel to the creek at approximately the 850-foot contour. A11 artifacts were mapped in place and all culturally altered materials were collected.

Two unifaces were recovered in Units 1-5 and many trimmed/utilized flakes were found in both groups of collection units (see Table 3 ). The abundance of trimmed/utilized flakes would tend to give support to the argument that more than lithic reduction was being carried out, at least at 41 CM 66 (Area B). Kelly and Hester (1975b) suggest, for quarry/workshop sites nearby (41 CM 84, $41 \mathrm{CM} 85$ and $41 \mathrm{CM} 86$ ), that some of the 7 ithic tools recovered may have functioned in the alteration of wood and other perishable items. The occurrence of lithic debitage at this quarry/workshop site has been compared with a controlled collection at a quarry/workshop site (41 CM 86) in the vicinity of Floodwater Retarding Structure No. 1 and described in Appendix I.

Area $C$ is about $325 \mathrm{~m}$ in length and is separated from Areas $B$ and $D$ by natura 1 drainages. Area D is separated from 41 CM 62 by another drainage and is roughly $400 \mathrm{~m}$ in length. The juniper and oak vegetation is very dense throughout both of these areas. Worked chert is found washed down the sides of a 11 the drainages which cut into $41 \mathrm{CM} 66$.

\section{$41 \mathrm{CM} 67$}

41 CM 67 is on the east side of Dry Comal Creek (Fig. 1). This site, along with 41 CM 69 which is directly opposite on the west side, is very lightly scattered and difficult to define. The main difficulty in describing attributes of this site lies in the fact that it is in the flood plain of the creek and is being repeatedly cut into by erosional activities. Vegetation varies from medium grass cover to thick brush.

\section{$41 \mathrm{CM} 68$}

41 CM 68 is on the west side of Dry Comal Creek. Four areas of lithic concentration were designated ( $A$ through $D$, running north to south) for this quarry workshop site (Fig. 1). As in the case of all the quarry/workshop sites, the boundaries of $41 \mathrm{CM} 68$ reflect the exposure of chert nodules.

Area $A$ is a band $20 \mathrm{~m}$ wide consisting of exposed and sampled chert nodules at its northernmost extreme. This area is about $150 \mathrm{~m}$ long (heading south toward Area B) and is found above and below the 848.8-foot contour line. The soil is a red clay and the vegetation is open grassland with juniper and oak trees. The 
TABLE 3. MATERIALS FROM CONTROLLED SURFACE COLLECTIONS AT 41 CM 66 (AREA B)

\begin{tabular}{|c|c|c|c|c|c|c|c|c|c|c|c|c|c|c|}
\hline \multirow[b]{2}{*}{ ARTIFACTS } & \multicolumn{5}{|c|}{ Units } & & \multicolumn{8}{|c|}{ Units } \\
\hline & 1 & 2 & 3 & 4 & 5 & TOTAL & $\%$ & 6 & 7 & 8 & 9 & 10 & TOTAL & $\%$ \\
\hline Bifaces & & 1 & & & & 1 & 20 & 1 & 2 & & & 1 & 4 & 80 \\
\hline Unifaces & 1 & 1 & & & & 2 & 33 & 2 & & & 1 & 1 & 4 & 67 \\
\hline Cores & & & & & & & & 2 & & 2 & 2 & 1 & 7 & 100 \\
\hline $\begin{array}{l}\text { Trimmed/Utilized } \\
\text { Flakes }\end{array}$ & 10 & 3 & 7 & 6 & 5 & 37 & 31 & 7 & 8 & 15 & 16 & 23 & 69 & 69 \\
\hline Primary Flakes & 5 & 5 & 7 & 1 & 2 & 20 & 41 & 2 & 8 & 9 & 2 & 13 & 34 & 59 \\
\hline Secondary Flakes & 16 & 6 & 21 & 9 & 12 & 64 & 44 & 5 & 23 & 10 & 20 & 25 & 83 & 56 \\
\hline Interior Flakes & 5 & 1 & 6 & 3 & 2 & 17 & 34 & 3 & 8 & 4 & 4 & 15 & 34 & 66 \\
\hline
\end{tabular}


artifacts found on the surface of Area A include large cores, quarry blanks, preforms, fragmented bifaces (of various sizes), unifaces and trimmed/utilized flakes.

Areas $A$ and $B$ are separated by a $50-m$ strip which is void of lithic material. The dense vegetation and the reduction in occurrence of chert were used to distinguish between the two areas. The soll in Area B is the same found at Area A. The concentration is found above and below the 848.8-foot contour line and within the easement line as one moves south. This area is about $300 \mathrm{~m}$ in length. Some of the artifacts observed in the two areas included unifaces (some with concave edges), large and small bifaces, cores and primary, secondary and interior flakes. There is a 25-m strip of disturbed surface area at approximately the center of the site. This disturbance is the direct result of construction of an underground pipeline.

Area $C$ is roughly $75 \mathrm{~m}$ south of Area $B$. A strip in between the two areas has the appearance of being cleared. Indeed, there are signs of trees being burned and uprooted throughout the length of $41 \mathrm{CM} 68$. The soil of Area $\mathrm{C}$ is an orange clay. The lithic scatter is lighter than Areas A and B, exhibiting a few scrapers, many cores and various bifaces (i.e., large, crude, fragmented and several preforms). More than half of Area C lies above the 848.8-foot contour.

Areas $C$ and $D$ are separated by $600 \mathrm{~m}$. A 11 of the $600-\mathrm{m}$ area separation, including Area D, lies within the easement line and is in a series of erosional drainage channels or a flood plain. The brush and grass are dense and the chert is lightly scattered. Area $D$ has less of a lithic concentration than do Areas $A$ and $B$, but this is probably due to the extent of erosion in this part of the site.

\section{$41 C M 69$}

41 CM 69, like 41 CM 67, is composed of two light 1ithic concentrations which are separated by a light and sporadic lithic scatter (Fig. 1). These two concentrations are at opposite ends of the site. The total length of the site is just over $900 \mathrm{~m}$ and is nearly all below the 848.8-foot contour. The southernmost area is directly north of campsite $41 \mathrm{CM} 62$ and is divided by a drainage. This area is above the creek bed, but as one moves north, the terrain drops to just slightly above the level of the creek. The vegetation varies from open grassland to dense juniper and brush.

\section{SUMMARY AND RECOMMENDATIONS}

The field work described in this report fulfills the recommendations for controlled surface collection and testing as suggested for the archaeological resources to be affected by Floodwater Retarding Structure No. 2 (Hester, Bass and Kelly 1975).

An extensive reconnaissance of the five quarry/workshop sites has been performed. Lithic concentrations within the sites have been isolated when possible. A controlled collection of surface artifacts has provided further information about quarry/workshop sites in the Comal River Watershed. 
The three sites tested are of importance in providing further information on predominantly Pre-Archaic and Early Archaic terrace campsites. The data obtained from $41 \mathrm{CM} 63$ and $41 \mathrm{CM} 105$ is considered to be sufficient considering the shallow and sometimes disturbed deposits. The survey phase of archaeological assessment for Floodwater Retarding Structure No. 2 (Hester, Bass and Kelly 1975) was to provide an inventory of the archaeological resources in the area along with recommendations for actions concerning these resources. The fact that the $41 \mathrm{CM} 63$ site was partially destroyed before the recommended testing commenced is very disturbing. The Soil Conservation Service should make every effort to have contractors avoid causing damage to archaeological resources which are recommended for further study. The value of the information that was lost can never be assessed.

The final site that was tested, 41 CM 62, provided us with valuable archaeological information regarding its use as an occupation and quarry site. Artifacts from this site ranged from the Late Paleo-Indian period through the Archaic period.

41 CM 62 still has the potential for providing valuable archaeological data pertaining to the aboriginal utilization of a preferred prehistoric campsite over an extended period of time. This is possible since the site has been relatively protected from damage in the past. It is our recommendation that $41 \mathrm{CM} 62$ remain unaltered; however, if that is not possible, then intensive excavation is recommended for any portions of the site to be affected by actions other than possible temporary inundation by the flood pool.

During February of 1978, Mr. B. J. Gunter (letter dated February 24, 1978), Project Construction Engineer of the Soit Conservation Service (Seguin office), indicated that the elevation of $41 \mathrm{CM} 62$ is roughly 848.8 feet. The above elevation is the same as that of the proposed extent of the flood pool of Floodwater Retarding Structure No. 2. Since less than half of $41 \mathrm{CM} 62$ is located below the flood pool line, the site should remain relatively unaltered in the event that impounded waters reach maximum level. However, the SCS should advise the contractors to keep heavy equipment off of the site area during the construction phase. 


\section{REFERENCES CITED}

Barnes, V. E.

1974 Geologic Atlas of Texas, San Antonio Sheet. Bureau of Economic Geology, The University of Texas at Austin.

Blair, W. F.

1950 The Biotic Provinces of Texas. Texas Journal of Science 2(1): 93-117.

Hester, T. R.

1971 Archeological Investigations at the La Jita Site, Uvalde County, Texas. Bulletin of the Texas Archeological Society 42:51-148.

Hester, T. R., F. A. Bass, Jr. and T. C. Kelly

1975 Archaeological Survey of Portions of the Comal River Watershed, Comal County, Texas. Center for Archaeological Research, The University of Texas at San Antonio, Archaeological Survey Report 6.

Hester, T. R., D. Gilbow and A. D. Albee

1973 A Functional Analysis of "Clear Fork" Artifacts from the Rio Grande Plain, Texas. American Antiquity 38(1):90-96.

Hester, T. R. and H. Kohnitz

1975 Chronological Placement of "Guadalupe" Tools. La Tierra 2(2): 22-25.

Howard, C. D.

1973 A Study of the Clear Fork Gouge. Bulletin of the Texas Archeological Society 44:51-60.

Kelly, T. C. and T. R. Hester

1975a Additional Archaeological Survey in the Dry Comal Watershed, Comal County, South Central Texas. Center for Archaeological Research, The University of Texas at San Antonio, Archaeological Survey Report 10.

1975b Archaeological Investigations at Four Sites in the Dry Comal Watershed, Comal County, South Central Texas. Center for Archaeological Research. The University of Texas at San Antonio, Archaeological Survey Report 15. 
USDA and SCS

1975 Comal River Watershed, Comal and Guadalupe Counties, Texas Environmental Assessment. United States Department of Agriculture and Soil Conservation Service. 


\section{APPENDIX I}

\section{A Comparison of Lithics From Some Quarry/Workshop Sites in Comal County, Texas}

Many quarry/workshop sites are to be found in the Comal River Watershed, Comal County, Texas. Some of these sites have been examined in the past by Kelly and Hester (1975b) in the form of controlled surface collections. The purpose of this section is to provide comparative data on collected lithic artifacts from four quarry/workshop sites: $41 \mathrm{CM} 66$ (examined during recent field work), $41 \mathrm{CM} 84,41 \mathrm{CM} 85$ and 41 CM 86 (Kelly and Hester 1975b).

Table 4 provides comparisons of controlled surface collections of $41 \mathrm{CM} 66$ and $41 \mathrm{CM} \mathrm{86}$. The size of the eight collection units from $41 \mathrm{CM} 86$ was $2.5 \times 6.0 \mathrm{~m}$ each (these were units A-H on the right side: Kelly and Hester 1975b). The size of the 10 collection units at $41 \mathrm{CM} 66$ was $1 \mathrm{~m}^{2}$ each. Similar artifacts were recovered at both sites.

Kelly and Hester (1975b) compare flake frequencies between the quarry/workshop sites in their study (41 CM 84, 41 CM 85 and 41 CM 86) and six other sites in the region (41 HY 72, 41 UV $21 \mathrm{~A}, \mathrm{~B}, \mathrm{C}$; $41 \mathrm{KE} 49$ and $41 \mathrm{TV} 151$; see Kelly and Hester 1975b for more detailed information). Primary, secondary and interior flakes were the categories studied. Their results indicate that the three Comal county sites were very similar in attributes. The flake frequencies from the collection of $41 \mathrm{CM} 66$ were compared to the other Comal County sites and the results correspond with those of Kelly and Hester (1975b; see Table 5). The frequency of primary flakes at 41 CM 66 is $22 \%$ while the mean of the other three sites is $23 \%$. A combination of primary and secondary flakes by Kelly and Hester (1975b) produced a frequency range of $55 \%$ to $75 \%$. The combination of the primary and secondary flakes from $41 \mathrm{CM} 66$ is $80 \%$.

These high primary and secondary flake frequencies and a scarcity of finished artifacts are further evidence to indicate the highly specialized nature of the quarry/workshop sites. It appears that the raw material was being reduced to portable form (quarry blanks/preforms) and removed to occupation sites (as suggested in Kelly and Hester 1975b). 
TABLE 4. COMPARISON OF TWO QUARRY/WORKSHOP COLLECTIONS

\begin{tabular}{|c|c|c|c|c|c|c|c|c|c|c|c|}
\hline & & & & Area & $\begin{array}{l}47 \mathrm{C} \\
\mathrm{B} ; \mathrm{U}\end{array}$ & Inits & $\begin{array}{ll}6 & \\
s & 1-1\end{array}$ & 10) & & & \\
\hline & 1 & 2 & 3 & 4 & 5 & 6 & 7 & 8 & 9 & 0 Total & $\%$ \\
\hline $\begin{array}{l}\text { Bifaces } \\
\text { (a11 types) }\end{array}$ & 1 & & & & & 1 & 2 & & & 5 & 2.0 \\
\hline Unifaces & 1 & 1 & & & & 2 & & & 1 & 6 & 2.0 \\
\hline $\begin{array}{l}\text { Trimmed/Utilized } \\
\text { Flakes }\end{array}$ & 10 & 3 & 7 & 6 & 5 & 7 & 8 & 15 & 16 & 100 & 27.0 \\
\hline Primary Flakes & 5 & 5 & 7 & 1 & 2 & 2 & 8 & 9 & 2 & 54 & 15.0 \\
\hline Secondary Flakes & 16 & 6 & 21 & 9 & 12 & 5 & 23 & 10 & 20 & 147 & 40.0 \\
\hline Interior Flakes & 5 & 1 & 6 & 3 & 2 & 3 & 8 & 4 & 4 & 51 & 14.0 \\
\hline TOTAL & 38 & 16 & 41 & 19 & 21 & 20 & 49 & 38 & 43 & 363 & 100.0 \\
\hline & & (Ri & ght & $\begin{array}{l}41 \mathrm{CN} \\
\text { side }\end{array}$ & $\begin{array}{l}\text { M } 86^{*} \\
; \text { Uni }\end{array}$ & * its & $A-H)$ & & & & \\
\hline & A & B & $C$ & $D$ & $E$ & $F$ & $G$ & $H$ & Tota 1 & $\%$ & \\
\hline $\begin{array}{l}\text { Bifaces } \\
\text { (a11 types) }\end{array}$ & 2 & 1 & & & & & & & 3 & .6 & \\
\hline Unifaces & 3 & 2 & 4 & & 1 & 2 & 1 & 9 & 22 & 4.0 & \\
\hline $\begin{array}{l}\text { Trimmed/Utilized } \\
\text { Flakes }\end{array}$ & 17 & 2 & 6 & & & 10 & 9 & 26 & 70 & 13.0 & \\
\hline Primary Flakes & 13 & 4 & 13 & 9 & 11 & & 4 & 23 & 77 & 14.4 & \\
\hline Secondary Flakes & 21 & 17 & 28 & 18 & 17 & 28 & 16 & 85 & 230 & 43.0 & \\
\hline Interior Flakes & 17 & 4 & 16 & 13 & 4 & 7 & 12 & 59 & 132 & 25.0 & \\
\hline TOTAL & 73 & 30 & 67 & 40 & 33 & 47 & 42 & 202 & 534 & 100.0 & \\
\hline
\end{tabular}


TABLE 5. COMPARISON OF FLAKE CATEGORIES AT FOUR QUARRY/WORKSHOP SITES IN COMAL COUNTY, TEXAS

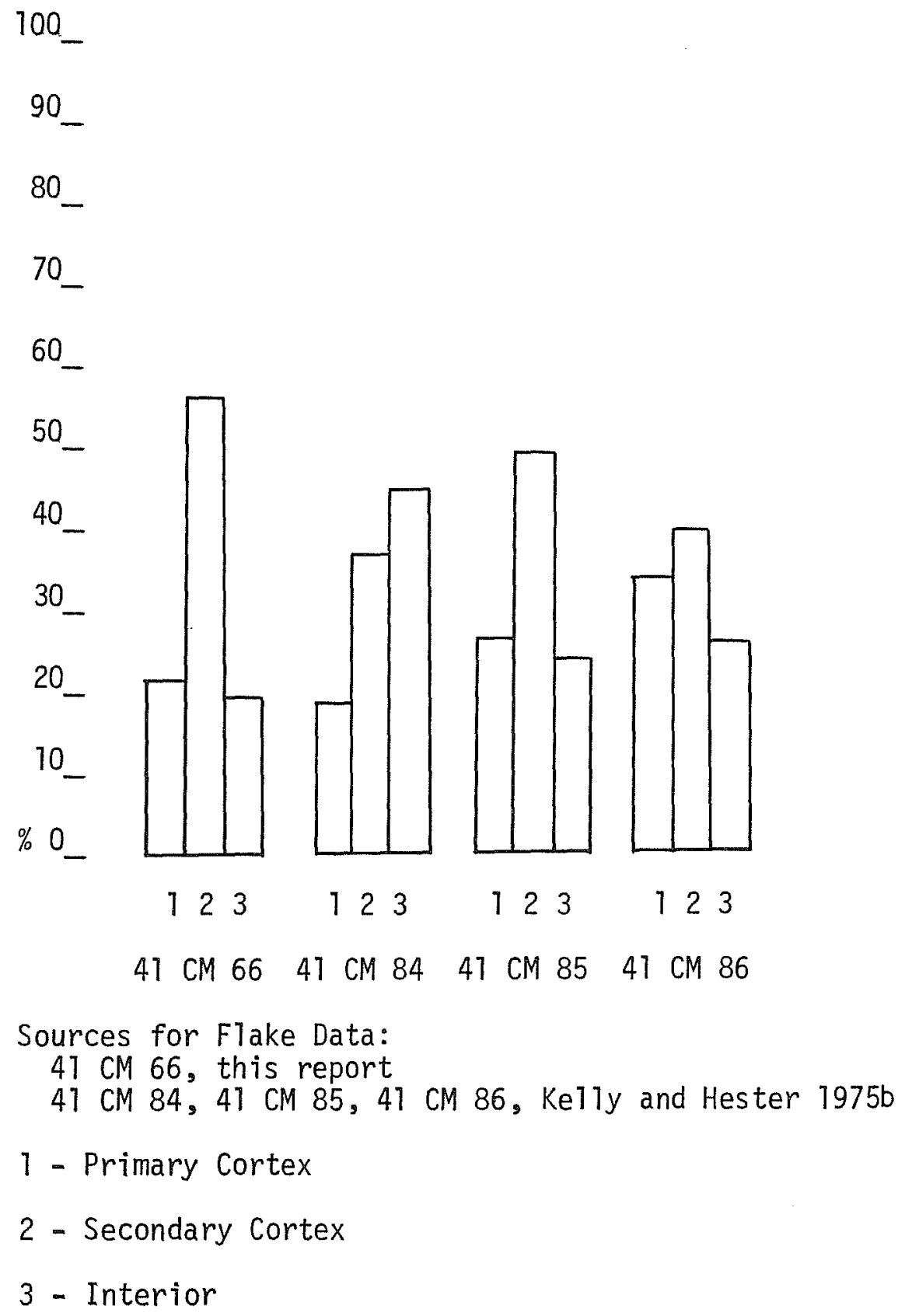




\section{GLOSSARY}

A general set of terms was established for the lithic artifacts discussed throughout this report. The terminology corresponds closely to the definitions in Kelly and Hester (1975b). Brief descriptions of the terms follow.

Cores: Nodular or tabular chert specimens which have one or more flakes removed.

Flakes: Fragments of chert detached from cores. The major kind of flakes are: primary (with up to $90 \%$ surface cortex), secondary (less than $90 \%$ cortex) and interior (no cortex). Trimmed/ utilized flakes are derived from the above categories and exhibit edge modification through use or retouch. All lithic debris was included in the flake categories whether or not a platform and bulb of percussion were present.

Unifaces: Usually thick flakes which have been modified on one face. Most of these unifacially flaked tools have steeply trimmed edges and were probably used as scrapers.

Bifaces: Chert specimens that have been bifacially flaked. Large, thick crudely worked bifaces (usually with some surface cortex) appear to be quarry blanks. Preforms represent a subsequent phase of reduction. The size of bifaces can range from small (less than $10 \mathrm{~cm}$ long) to very large (10 $\mathrm{cm}$ or more in length). 
